\title{
Myths of the State in the West European Middle Ages
}

\author{
By LENNART EJERFELDT
}

"The Germanic Ruler embodied a sacred and magical mythos because of his blood kinship with distant ancestors; this was now replaced by an equally sacred mythos that was derived from divine sanction and grace. Kingship ceased to be a matter of blood and became a matter of divine intervention: the blood charisma gave way to a charisma sustained by grace."

In these words one of the most prominent scholars of medieval constitutional history describes the succession of one myth of the State and the kingship to another: Walter Ullman of the end of the Merovingians A.D. $75^{1.1}$

The eminent ideological and constitutional significance of this happening is evident from the fact that the disposing of the last Merovingian and the elevation of Pippin the Short from major domus to king indicated no real change in the power relations. The power and the wealth of the Merovingians had been in decline since at least a century, and the family that was to become the Carolingians had for several generations enlarged their power from the position as major domus. What happened $75 \mathrm{I}$ was the legal confirmation of this development. ${ }^{2}$

The obvious hesitation to deprive the weak and impoverished Merovingians of their rank and royal name has been interpreted as being derived from fear to commit an outrage against the royal house and the royal blood. Only the introduction of a quite new sanction of the royal legitimacy could

1 W. Ullman, The Carolingian Renaissance and the Idea of Kingship, London 1969 , p. 54 .

2 J. M. Wallace-Hadrill, The Long-Haired Kings, London 1962, p. 231 ff. The author stresses particularly the growing influence of the Carolingian maiors in the ecclesiastical field, sponsoring the missionary churches of the eastern frontier, and cultivating the relations with the Papal See. 
accomplish this revolution. The leading Frankish churchmen consulted the pope Zacharias, who declared "that it would be better to call him King, who had the power, than him who persisted without royal power." Not to disturb the order therefore the pope enjoined Pippin to become king. ${ }^{1}$ "The blood charisma" of the Merovingians is symbolized by their proverbially famous long hair. The Frankish Royal Annals and following them Einhard tell of the last Merovingian king Childeric, "falsely named king," that he was tonsured and sent into a monastery. ${ }^{2}$ Shorn of their long hair the Merovingians were obviously unfit to royal rank and power. Several times before the ignominious end of the family the shearing of the long hair had played an important role in its tangled dynastic fights and stratagems.

The hair-cut is always connected with attempts to coerce a pretendent into a monastery or into clerical ranks. And conversely a cleric once let his hair grow long and thereupon attained the kingship. We know from the sources that deprivation of the long hair incapacitated a Merovingian from being in the royal succession, and that the cutting of the hair was experienced as a painful humiliation. ${ }^{3}$ Substantial positive evidences of the long hair as the sign or the embodiment of the royal charisma of the blood are missing.

Most German scholars take the interpretation of the long hair as the outward sign of their "Königsheil" and the shearing of the last Merovingian as a transformed Germanic sacrifice of the king. ${ }^{4}$ Wallace-Hadrill in his

I On the royal elevation of Pippin the thorough treatment in H. Büttner, "Aus den Anfängen des abendländischen Staatsgedankens", Das Königtum, ed. Th. Meyer (Vorträge und Forschungen, 3), 1956, p. 153 ff. Annales regni Francorum: "Et Zacharias papa mandavit Pippino, ut melius esset illum regem vocari, qui potestatem haberet, quam illum, qui sine regali potestate manebat, ut non conturbaretur ordo, per auctoritatem apostolicam iussit Pippinum regem fieri." (Büttner, p. 158, n. 13.)

2 Wallace-Hadrill, p. 245 f.

3 R. Buchner, "Das merowingische Königtum", Das Königtum, I956, p. I47.

${ }^{4}$ H. Mitteis, "Formen der Adelsherrschaft im Mittelalter", Festschrift Fritz Schulz, I95I, p. 237 f.: "Als Häupter der austrasischen Aristokratie sind im 7 . Jahrhundert die arnulfingisch-karolingischen Hausmeier emporgekommen, und es war nichts anders als des germanischen Königsopfer in veränderter Form, wenn sie die letzten, regierungsunfähig gewordenen Merowinger vom Throne stiessen und sich selbst ein neues Charisma, nunmehr das der christlichen Königsweihe, um die Schultern legen liessen. Lange hatte die Ehrfurcht vor dem merowingischen Königsheil diesen Staatsstreich verzögert."

II -724135 H. Biezais 
masterly study of the Long-Haired Kings is much more cautious, but puts perhaps unduly much stress on the act as merely a deep humiliation."

I have elsewhere discussed the problem of a pre-Christian "Germanic charismatic conception of the kingship.". Here is only space to outline the characteristics of the kingdoms created in Western Europe by the Barbarian invasions. The social substrate and the economic infrastructure in the new Germanic kingdoms were to a great extent Roman, but the basic principle of the state was quite another. "The end of the Roman Empire in the West meant the decline of the ideas and practice of public law in the barbarian kingdoms. The State itself became weak, public law was submerged in private law, and in the ninth to eleventh centuries feudalism reflected the triumph of private rights over the public interest." 4

In the first centuries of the barbarian kingdoms the most striking feature is the gens, the tribe, as the principle of unity, even if the ethnic homogeneity often was missing. The myth of the Germanic State of the early Middle Ages was in the first place a myth of the common origin of the gens. ${ }^{5}$

These histories of tribal origins have some times been influenced by powerful Ancient literary patterns, especially the Trojan myth of Virgil. But the concern of presenting the origin of the gens in mythical form is no doubt Germanic. And it seems probable that the the tribal origins are

1 Wallace-Hadrill, p. 246: "We cannot therefore be sure that the anointing with chrism of the Carolingians was intended to compensate for the loss of magical properties of blood, symbolized by long hair."

${ }^{2}$ L. Ejerfeldt, "Helighet, karisma och kungadöme i forngermansk religion", (Summary in German), Kungl. Humanistiska Vetenskapssamfundet $i$ Uppsala, Arsbok $1969-1970$, p. I12 ff. "The Germanic 'charismatic' conception of Kingship" is the head-line of an excellent chapter in F. Graus, Volk, Herrscher und Heilige im Reich der Merowinger, Praha I965, p. $313 \mathrm{ff}$.

${ }^{3}$ In late Antiquity res publica was exclusively denoting the Roman Empire, and its successor the Byzantine Empire. This is the usage even in Gregory of Tours. See W. Suerbaum, "Vom antiken zum frühmittelalterlichen Staatsbegriff", Orbis Antiquus, I6/17, 1961, p. $303 \mathrm{ff}$.

4 G. Post, Studies in Medieval Legal Thought, Princeton 1964, p. 257.

${ }^{5} \mathrm{R}$. Wenskus, Stammesbildung und Verfassung-Das Werden der frühmittelalterlichen gentes, Köln-Graz 1961; A. Borst, Der Turmbau von Babel. Geschichte der Meinungen über Ursprung und Vielfalt der Sprachen und Völker, 2: 1, Stuttgart 1958, p. $437 \mathrm{ff}$. 
more ancient than the genealogies of royal families with alleged divine ancestors. ${ }^{1}$

The kingship among the Germanic tribes was secondary in relation to the tribe. The king was rex Francorum; the king of a certain country or geographic territory is a later conception. Ullman is right in stressing "the ascending theme of government" in the barbarian kingdoms. ${ }^{2}$ The power comes from below; the king is an exponent of the tribe. All the Germanic words for "king" are derivations from terms for "kin, people, tribe." The limitation of the power of the king is also indicated by institutions like the right to resistence, the possibility to depose the king, the participation by all free men in the judicial and criminal procedure through self-help and blood feud. ${ }^{4}$

Gens was the Latin term to render "tribe" as the political unity in the barbarian kingdoms, and gentes and gentilis lost their exclusive reference to "pagans" and "pagan", as translations of the Greek Biblical éthnē and ethnikós, literally only meaning "peoples" and "popular." Isidor of Seville defines neatly: "gens est multitudo ab uno principio orta."

In this shift of significance also the word, its present form being deutsch, was involved. Wulfila had translated the Greek adverb ethnikốs by piudisko, as the Greek word a formation to "people, tribe." The same word is found in the West Germanic languages in the same sense, but generally it was used to distinguish the barbarian, principally the language, from the Roman and Latin. In the eighth century it became the designation of the Germanic language and the Germanic-speaking people in the Frankish kingdom. ${ }^{5}$

\footnotetext{
1 For an immensely erudite plea for the ancient Germanic character of the tales of tribal origins, K. Hauck, Goldbrakteaten aus Sievern, München 1970. Another view in Graus, Volk, Herrscher und Heilige.

2 W. Ullman, Principles of Government and Politics in the Middle Ages, London I96I, p. I9 ff.

s W. Schlesinger, “Über germanisches Königtum”, Das Königtum, 1956, p. 106 ff.,

4 The chapter on The Bloodfeud of the Franks in Wallace-Hadrill, p. I 2 I $\mathrm{ff}$, outlines the ideological differences between the common self-help and bloodfeud of the Merovingian time and attempts of Charlemagne to make the legislation and legal procedure a royal matter, but questions the differences in savagery and bloodshed.

5 R. Wenskus, "Die deutschen Stämme im Reich Karls der Grossen", Karl der Grosse. Lebenswerk und Nachleben, I, 1965, p. $178 \mathrm{ff}$. 
This "gentilism" as political consciousness no doubt had its counterpart on the constitutional level in the State held together by personal bonds. ${ }^{1}$ That was something quite different from the Greek polis as well as the Roman respublica or empire, where "Roman" had lost its ethnic or national meaning. ${ }^{2}$

The "sacred mythos ... derived from divine sanction and grace" and the royal "charisma sustained by grace" got its foremost expression in the rex gratia Dei-formula. Gratia Dei, translating khariti theoũ, "by the grace of God," occurs in exactly this form only twice in the New Testament. Ullman mentions I. Cor. XV. Io, where St. Paul states "Gratia Dei sum id quod sum."3

Gratia Dei and its Greek prototype was first used as a formula in the documents of some councils in the fourth century. It was frequently varied with favor or benevolentia instead of gratia, or expressions like Deo favente. It is worth noting that gratia has the meaning of "favour, benignity, benevolence," not "gift of grace." Rex gratia Dei does not mean that the kingship is a gift of God, a charisma in the sense of the New Testament. Gratia had a rather legal sense and its use in the formula gratia regis was well established in Merovingian times. ${ }^{4}$

The Carolingian kingship and the Carolingian State had a theocratic

${ }^{1} \mathrm{H}$. Beumann, "Zur Entwicklung transpersonaler Staatsvorstellungen", Das Königtum, p. 221: "Dem Gentilismus als politischem Bewusstsein korrespondiert nun ohne Zweifel auf der Ebene der verfassungsgeschichtlichen Realstruktur der 'Personenverbandsstaat'."

2 The Roman name was inherited by the Byzantines, which preferred the designation Rhomaioi until the Byzantine Renaissance in the fourteenth century liberated Hellenes from its New Testament meaning "pagans".

3 Ullman, Principles, p. I $8 \mathrm{f}$. The other instance of gratia Dei in the New Testament is the obscure Hebr. II. 9-10. Some commentators think that Vulgata here is based on an inferior reading. Despite its connection with "crowning" (gloria honore coronatus) this passage seems to have played no role in the development of the rex gratia Dei-idea and the coronation rite.

4 The latest extensive treatment of the formula is J. A. Dabbs, Dei Gratia in Royal Titles, The Hague 197I. Contrary to most other scholars he seems to believe that gratia Dei in the title of Clovis is genuine. For the pre-history of the formulaic use by kings from the eighth century, see W. Ensslin, "Gottkaiser und Kaisertum von Gottes Gnaden", Sitz.-Ber. der Bayer. Akad., phil.-hist. Abt., I943: 6, p. 120 ff.; F. L. Granshof, La "gratia" des monarques francs (Anuario de estudios medievales, 3), Barcelona 1966, p. $9 \mathrm{ff}$. 
and ecclesiological cast quite unknown to the previous christianized barbarian kingdoms. Expression of this was not only the rex gratia Dei-ideology, but also the massive contribution of the church in the new royal initiation rites, anointing and crowning. Both referred directly to the Bible: the ruler as the Lord's Anointed and therefore another Christ or partaking in Christ's rule, the crown as the crown of Life, corona vitae, but also the sign for co-reigning with Christ. ${ }^{1}$

This is what Ullman calls "the descending theme of government," where the legitimation and the power is bestowed from above. It had also consequences for the relationship between king and people. The law became a written code, enforced by the king, fighting blood feuds and mutual oaths and pledges.2 The king was the tutor regni and this his tuitio or tutela, his protection of the realm and its inhabitants was expressed with the latinized Germanic term mundeburdium, from mund (cf. German Vormund, mündig). Ullman takes this to be a very ancient Germanic conception of the relationship king-people, but that is perhaps to be doubted. ${ }^{3}$ Its connection with the handling in the Roman law of the respublica as a minor, in need of a tutor seems more obvious. But this theme is not elaborated in the Middle Ages prior to the canonists of the twelfth century.4

${ }^{1}$ Different interpretations of the precise relationship between king and Church in Carolingian times are exposed in K. F. Morrison, The Two Kingdoms. Ecclesiology in Carolingian Political Thought, Princeton 1964, p. $26 \mathrm{ff}$.

C. A. Bouman, Sacring and Crowning. The Development of the Latin Ritual for Anointing of Kings and the Coronation of an Emperor before the XI. Century, Groningen I957.

P. E. Schramm, ",Mitherrschaft im Himmel': Ein Topos des Herrscherkults in christlicher Einkleidung", Polychronion. Festschrift Franz Dölger, 1966, p. 480 ff.

2 A good analysis in a book with a rather puzzling and misleading title: J. Goebel, jr, Felony and Misdemeanor. A Study in the History of English Criminal Procedure, New York 1937, chapter II Frankish Crown Procedure and the Growth of Public Order, p. 62 ff.

${ }^{3}$ Ullman, The Carolingian Renaissance, p. 45: "What provides a fascinating background to this escalation of monarchic powers is the utilization of the thoroughly Germanic governmental concept of the Munt. Now the Munt had been operative as an integral element of kingship since the ancient Teutonic age and its composite parts did not need any radical change as a result of the infusion of Christian ideas." See also p. I77.

4 Goebel, p. 48: “... it is difficult to account for the king's protection (mundium) as some have done, as a guardianship substituting for the sib as the latter declined. And the explanation that it is evolved out of the tuitio of the Roman law does not 
In Carolingian times there were tendencies to distinguish the kingdom and the kingship. The specific rights of the kingdom, irrespective of the actual king, were in the ninth century already known as the regalian rights, and the royal property was distinguished from the king's property. But this Christ-centered kingship, to employ a term of Kantorowicz's, was not able to conceive the commonwealth, the ancient respublica, as something abstracted from the dominion of the kingship. In the Germanic languages respublica was rendered kunigriche or hertoum, i.e. "kingdom" or "dominion," and publicus was translated with words for "royal."1 The classical vocabulary of statecraft was never quite extinct during the early Middle Ages, but its original references became more or less extinct with the barbarian invasions, and were not recovered by the theocratic kingship of the Carolingian epoch. ${ }^{2}$

In the development of transpersonal conceptions of the state, some of the symbols of royal power and dignity played a crucial role; the throne and the crown. The imperial Carolingian throne in Aix-la-Chapelle, called solium regni and sedes imperii, was used in that way. ${ }^{3}$ From the turn of the millenium the crown became the most prominent symbol of kingship, its dignity and perpetuality. The coronation rite is older than the use of crown as an abstraction for the kingship. The Biblical references were 2. Tim. II. I2, Jac. I.I2 and Apoc. II.ro. ${ }^{4}$ The invisible crown, without any implicit allusion to a visible crown, emerged as the main symbol of the reign in the middle of the twelfth century. In France it had more patriotic overtones; in England the crown was connected with the law, the administration and

account for all its peculiarities ... But in its earliest phases the protection was probably no more than the king capitalizing his political power and particularly the control of his own court for the benefit of favourites." The Roman law of Emperors Diocletian and Maximianus cited in E. H. Kantorowicz, The King's Two Bodies. A study in Mediaeval Political Theology, Princeton 1957, p. 374: "Res publica minorum iure uti solet ..."

1 Beumann, p.; Igo ff.; H. Vollrath-Reichelt, Königsgedanke und Königtum bei den Angelsachsen, p. 49 ff.

a 'The polarity polites-idiotes, the man's roles in public and in private life among the Greeks as well as the abstractions derived from Greek polis and Latin civis, politeia, civitas etc. could neither be applied to the gentilistic nor to the theocratic kingship.

3 Beumann, p. 205 ff.

4 Beumann, p. 2 II. 
the royal demesne. From this time we have the well-known British institution, the coroner attested as custos placitorum coronae or coronator. "The Crown" has down to our own time been the dominant expression of the transpersonal character of the kingdom. ${ }^{1}$

One of the cruder expressions of this distinction between the king and the kingship is linked with the often cited and often misunderstood ceremonial exclamation: "Le roi est meurt. Vive le roil" During the time from the death of the king until the interment the kingship was represented by an effigies of the deceased. Only immediately after the funeral the new king was able to ascend the throne, and at that moment the continuity of the kingship was expressed in the exclamation. ${ }^{2}$

The wrestling with modes of representing kingship and dominion and expressing the continuity and transpersonal character of the State, took a new direction with the development of Canon Law in the twelfth century. The Roman concept of corporation, for many centuries fallen into neglect, was applied by the canonists to the realities of reign and church. The feudal, personal ties of fidelity, gave way to general principles of law and order. The clumsy attempts of the early Middle Ages to express the legal continuity of the Church, e.g. by the fiction of Christ or of the patron saint as the owner of church property, were superseded by more sophisticated formulations. ${ }^{3}$

How Roman and Canon Law conceptions of legal body or corporation sole is combined with the theological notion of Corpus Christi and Christ's two natures is the subject of Kantorowicz' masterly exposition in The King's Trwo Bodies. This distinction between the King's body politic and his body natural is conceived in analogy with Christ's divine and human natures.

\footnotetext{
${ }^{1}$ Generally Corona regni. Studien über die Krone als Symbol des Staates im späteren Mittelalter, ed. M. Hellmann (Wege der Forschung, 2), Darmstadt I96I; Kantorowicz, p. $336 \mathrm{ff}$.

2 P. Geiger, "'Le roi est meurt, vive le roi"”. Das Bild des Königs bei den französischen Königsbegräbnissen", Schweizerisches Archiv fïr Volkskunde, 32, 1932, p. I ff.; R. Giesey, The Royal Funeral Ceremony in Renaissance France (Travaux d'Humanisme et Renaissance, 37), Geneva 1960; W. Brückner, Bildnis und Brauchtum. Studien zur Bildfunktion der Effigies, Berlin I 966.

s Kantorowicz, Post, and recently the painstaking study of the entire terminology of corporations and juristic collectivities in the High Middle Ages: P. MichaudQuantin, Universitas, Expressions du mouvement communautaire dans le moyen-Age latin, Paris 1970.
} 
Kantorowicz distinguishes three principles of medieval kingship after the christianization of barbarian society. The Christ-centered kingship is based on the rex gratia Dei-conception and the participation in the kingship of Christ. This was often connected with ideas of superiority of the Emperor and the regnum over the Pope and the sacerdotium. The second is the law-centered kingship, with the king as primarily law-giver or the law animate, himself unrestricted by the law, absolute. ${ }^{1}$

The third type of medieval royal ideology is according to Kantorowicz, the Polity-centered kingship. This was developed after the rediscovery of Aristotle and the classical tradition of politics.

Aristotle's Politics was translated into Latin in the middle of the thirteenth century and not long afterwards Thomas Aquinas wrote his commentary, which was to be the most powerful influence in de-mythologizing kingship and reign and delineating a typology of governments and a doctrine of shared powers. ${ }^{2}$

Thomas coined the term regimen politicum in contrast to regimen regale, and he meant a regimen politicum be at hand "when he who rules has the power circumscribed according to laws of the state" or with another sentence: "when the ruler rules according to laws laid down by the political constitution." 3 From the thirteenth century on democratic and populist theories of the commonwealth, the politeia or respublica, are formulated. The wheel has turned full circle.

Although the Germanic tribes allotted to their kings sacral functions and their royal families corroborated the claim to prime rank with divine genealogies, the barbarian kings held their power with the consent of the tribal assembly. The king could under circumstances be deposed and the legislation and criminal procedure was mainly a task for individuals and families.

With the christianization and clericalisation of the society, in the Frankish kingdom indicated by the papal role in the end of the Merovingians and the

\footnotetext{
${ }^{I}$ Kantorowicz, p. $132 \mathrm{ff}$. on the conception of lex animata and its origin in the Greek nómos émpsykhos.

2 Ullman, Principles of Government, the chapter Towards Populism, p. $23 \mathrm{I} \mathrm{ff;}$ T. Gilby, Principality and Polity, London I 958.

${ }^{3}$ Politicum autem regimen est, quando ille qui praest, habet potestatem coarctatam secundum aliquas leges civitatis. Ullman, Principles of Government, p. 255.
} 
ascension of Pippin, the kingship got a new foundation in the gratia Deiidea. All power was bestowed from above by the mediation of the bishops.

The feudal structure of the reign relied upon personal bonds of fidelity, but the people's law of the Germanic times became the king's law. The theme of the absolute king, above and master of the law, was to stay long in Western history.

A thousand years ago the first steps to express transpersonal conceptions of State and kingship were taken by means of abstract use of state symbols as the crown.

The naturalness of human society and of the State and the possibility of different forms of legitimate government was first explicitly propounded by Thomas Aquinas following the rediscovered Aristotle. The High Scholasticism usually regarded as the apogee of the predominance of Church and theology even in secular matters, means in the political theory the beginning of the de-mythologizing and secularizing of the State. The Aristotelian influence fused with the theories of representation that the canonists of the preceding century had developed.

Historically the absolute king and the kingship by the Grace of God reached its culmination only in the seventeenth century, but from the Late Middle Ages ideas of the relativity of governmental forms, of sovereignty of the people and the right to resort to violence in order to get rid of an unjust and tyrannical authority developed. 